\title{
Papers
}

\section{Systematic review of misdiagnosis of conversion symptoms and "hysteria"}

Jon Stone, Roger Smyth, Alan Carson, Steff Lewis, Robin Prescott, Charles Warlow, Michael Sharpe

\begin{abstract}
Objective Paralysis, seizures, and sensory symptoms that are unexplained by organic disease are commonly referred to as "conversion" symptoms. Some patients who receive this diagnosis subsequently turn out to have a disease that explains their initial presentation. We aimed to determine how frequently this misdiagnosis occurs, and whether it has become less common since the widespread availability of brain imaging. Design Systematic review.

Data sources Medline, Embase, PsycINFO, Cinahl databases, and searches of reference lists.

Review methods We included studies published since 1965 on the diagnostic outcome of adults with motor and sensory symptoms unexplained by disease. We critically appraised these papers, and carried out a multivariate, random effect, meta-analysis of the data.

Results Twenty seven studies including a total of 1466 patients and a median duration of follow-up of five years were eligible for inclusion. Early studies were of poor quality. There was a significant $(\mathrm{P}<0.02)$ decline in the mean rate of misdiagnosis from the 1950 s to the present day; $29 \%$ (95\% confidence interval $23 \%$ to $36 \%$ ) in the $1950 \mathrm{~s} ; 17 \%(12 \%$ to $24 \%)$ in the $1960 \mathrm{~s} ; 4 \%(2 \%$ to $7 \%)$ in the $1970 \mathrm{~s} ; 4 \%(2 \%$ to $6 \%)$ in the $1980 \mathrm{~s}$; and $4 \%(2 \%$ to $6 \%)$ in the 1990 s. This decline was independent of age, sex, and duration of symptom in people included in the studies.

Conclusions A high rate of misdiagnosis of conversion symptoms was reported in early studies but this rate has been only $4 \%$ on average in studies of this diagnosis since 1970 . This decline is probably due to improvements in study quality rather than improved diagnostic accuracy arising from the introduction of computed tomography of the brain.
\end{abstract}

\section{Introduction}

Patients with motor and sensory symptoms-such as paralysis, seizures, and blindness - that are unexplained by disease remain commonplace in neurological practice and account for 1-9\% of inpatients and outpatients. ${ }^{1}$ Modern psychiatric diagnostic classifications use the term conversion disorder (Diagnostic and Statistical Manual of Mental Disorders, fourth edition (DSM-IV) or dissociative motor disorder (ICD-10, international classification of diseases, 10th revision) for symptoms that suggest a neurological diagnosis but are not due to disease or malingering. They have also been called "psychogenic," "non-organic," "hysterical," "medically unexplained," and sometimes "functional" symptoms, though we have called them all conversion symptoms here.
Doctors often feel uneasy about making a diagnosis of conversion symptoms. This is, in part, due to the considerable influence of studies that have suggested that misdiagnosis is unacceptably common. The best known of these studies was published by Slater in 1965. It described a misdiagnosis rate of $33 \%$ in patients with "hysteria" and concluded with the memorable warning that the diagnosis was nothing more than "a delusion and a snare."

We carried out a systematic review of all relevant studies published since 1965 to obtain the best estimate of how often patients with an initial diagnosis of conversion symptoms are subsequently given a disease diagnosis that, in hindsight, explained their original symptoms. We also investigated whether the rate of misdiagnosis is lower in more recent studies, especially those carried out since the widespread availability of brain imaging.

\section{Methods}

\section{Search strategy for studies}

We searched Medline (from 1966), CINAHL (from 1982), Embase (from 1980), and PsycINFO (from 1965) to December 2003. We used all database controlled vocabulary headings for conversion disorder and hysteria and the text words psychosomatic, psychogenic, somatization, unexplained, conversion, nonorganic, dissoc*. They were combined with text words for paralysis, paresis, sensory disturbance, deafness, hearing, vis*, blind*, and movement disorders. References for pseudoseizures were searched with the text words: pseudoseizure, non-epileptic, psychogenic seizure, hysterical attack. All references under the heading "conversion disorder" or with the text word hysteri* were also examined. We reviewed the titles and abstracts online and obtained copies of all publications that might conceivably contain relevant data. The reference lists of all these publications were also examined for additional relevant studies published after 1965 .

\section{Study inclusion and exclusion}

We included studies if the participants were aged $>16$; symptoms were described as medically unexplained, nonorganic, psychogenic, hysterical, conversion, or functional; the symptoms described were motor (paresis, paralysis, movement disorder, gait disorder), sensory (numbness or paraesthesia), loss of vision, loss of hearing, or episodes resembling epilepsy (pseudoseizures); the study was of more than 10 patients; and there was a follow-up period of more than six months, at which time some attempt was made to review the accuracy of the initial diagnosis. We excluded studies of patients with other somatoform diagnoses including somatoform pain disorder and 
somatisation disorder (multiple chronic symptoms unexplained by a general medical condition attributable to several bodily systems). No studies were excluded on the basis of language.

We considered that a misdiagnosis of conversion disorder had occurred when the investigators concluded that, with hindsight, most of a patient's original symptoms or signs were better explained by a disease. We used the term "disease" to describe a clearly defined pathology (for example, stroke) or a diagnosis that is generally accepted as a medical condition (for example, migraine, dystonia). We did not record a misdiagnosis if the patient had an initial diagnosis of disease with a comorbid diagnosis of "hysteria" that was subsequently revised to a diagnosis of disease alone. Neither did we record psychiatric misdiagnosis. A symptom such as leg paralysis cannot in hindsight be attributed to another psychiatric diagnosis such as depression even if comorbid depression was missed at the time of initial diagnosis.

\section{Data extraction and analysis}

Four investigators (JS, RS, AC, and MS) independently reviewed all reports and a fifth $(\mathrm{CW})$ arbitrated in cases of disagreement. We collected data on the nature of the symptoms; the sex and mean age of the participants; the setting in which the patient was seen; whether sampling was consecutive or non-consecutive, and retrospective or prospective; the years in which the patients initially received the diagnosis; the duration and completeness of follow-up; the method of diagnosis used at follow-up; and the frequency and nature of any misdiagnoses and causes of death (where this was recorded). We attempted to contact authors to clarify data when these were uncertain.

We calculated the rate of misdiagnosis in each study as the "number of patients misdiagnosed" divided by the "number of patients followed up including those who died." Firstly, we determined an overall rate of misdiagnosis both by simple pooling of the data and by a random effects model. Secondly, we summarised the data according to the date the initial "conversion" diagnosis was made (rather than study publication date). If the dates of recruitment of patients were unavailable we estimated them using the published mean or range of duration of follow-up (allowing one extra year for publication). We summarised these data by charting individual studies according to the midpoint of their recruitment period, and, because this may not reflect adequately the wide variation in the duration of patient recruitment, we also calculated the proportion of patients with a misdiagnosis for each five year and ten year time period from 1950-99 using random effect models. Thirdly, we used a general linear mixed model to examine the relation between the proportion of patients with a misdiagnosis and the variables of age, sex, duration of follow-up, and midpoint of study recruitment. All analyses were performed with study effects fitted as random, using PROC GLIMMIX for SAS 9 (SAS Institute, Cary, NC).

\section{Results}

\section{Included and excluded studies}

The table shows the 27 studies eligible for inclusion. ${ }^{3-29}$ Seven other studies met some of the eligibility criteria but not others and were excluded: two studies had fewer than ten patients ${ }^{30}{ }^{31}$; in two studies patients were still under investigation when they were misdiagnosed ${ }^{32}{ }^{33}$; in one study conversion hysteria had been a differential diagnosis only ${ }^{34}$; in one study most patients were children when they were diagnosed ${ }^{35}$; and one study had only a four month follow-up period. ${ }^{36}$
Other reasons for ineligibility were studies that simply reported comorbidity with a disease diagnosis ${ }^{37-39}$; studies reporting the proportion of patients with a specific disease (for example, dystonia) who had previously received a diagnosis of hysteria $^{40-43}$; studies reporting small series of misdiagnosed patients with no denominator ${ }^{4-46}$; and follow-up studies not reporting the presence or absence of misdiagnosis.

\section{Analysis of misdiagnosis}

The overall proportion of misdiagnoses for the whole time period was $8.4 \%$ (95\% confidence interval $7.1 \%$ to $9.9 \%)$ with simple data pooling but $4.2 \%$ (2.4\% to $7.1 \%)$ with the more rigorous random effects model. There has been a clear decline in the rate of misdiagnosis over the past 50 years, from $29 \%$ in the $1950 \mathrm{~s}$ to $17 \%$ in the $1960 \mathrm{~s}, 4 \%$ in the $1970 \mathrm{~s}, 4 \%$ in the $1980 \mathrm{~s}$, and $4 \%$ in the 1990 s (fig 1 ). This decline was significant with the random effects model $(\mathrm{P}<0.02)$ even after adjustment for patient's age, sex, and duration of symptoms (none of which were related to misdiagnosis in this random effects model). Individual studies were plotted against the midpoint of date of recruitment with an indication of the case definition used (fig 2).

\section{Quality of studies}

Many of the studies, especially earlier ones, ${ }^{3-5}$ were of poor quality and ambiguous. If in doubt, we erred on the side of overestimating the rate of misdiagnosis. For example, in Slater's study, cases of "cortical atrophy," deaths caused by "coronary thromboses . . . related somewhat indirectly with the presenting symptoms," and "duodenal and gallbladder disease" were counted as misdiagnoses even though the presenting symptoms were not described. ${ }^{2}{ }^{3}$ We included the 29 patients reported by Reed solely because of the sentence "The 'conversion symptoms' in this group were such things as pain later found to be due to inoperable cancer of the uterus" with no further details given. ${ }^{4}$

\section{Case definition and the nature of the symptom}

In eight studies the nature of the conversion or "hysterical" symptoms was unclear. ${ }^{3-8} 162627$ Most of these were older studies of more loosely defined "hysteria." Although the symptoms were largely neurological, there were also patients with symptoms such as abdominal pain that would not now be regarded as conversion symptoms. We also undertook an analysis of symptom specific studies to see if the misdiagnosis rate differed between symptom types. This indicated that the rate of misdiagnosis of pseudoseizures ${ }^{11-13} 1718{ }^{22}{ }^{23}$ was similar to that reported for motor and sensory symptoms ${ }^{10} 15202124252829(2.6 \%(\mathrm{n}=350) v 4.0 \%$ $(\mathrm{n}=373), \mathrm{P}=0.28)$.

\section{Setting}

Only two studies were of outpatients, ${ }^{25}{ }^{29}$ in whom investigation may be less intensive, and seven studies were of patients referred to psychiatrists. ${ }^{4-6} 81419$ Psychiatric samples are likely to be biased because they comprise patients whom the neurologist was confident enough to refer and who were willing to accept a psychiatric referral.

\section{Sampling of study population}

Patients were recruited prospectively in only four studies. ${ }^{19} 202429$ One problem with retrospective studies is that they are often of patients who have received a diagnosis of "conversion disorder." As neurologists rarely use this diagnosis ${ }^{47}$ these studies are likely to be biased by including only patients who have seen a psychiatrist. 
Studies reporting misdiagnosis in conversion disorder, hysteria, or conversion symptoms since 1965

\begin{tabular}{|c|c|c|c|c|c|c|c|c|}
\hline Author & $\begin{array}{l}\text { Years of } \\
\text { diagnosis }\end{array}$ & $\begin{array}{l}\text { Follow-up } \\
\text { duration } \\
\text { (months)* }\end{array}$ & $\begin{array}{l}\text { Follow-up } \\
\text { rate } \\
(\%)^{*}\end{array}$ & Symptoms & Setting & $\begin{array}{l}\text { Method of } \\
\text { diagnostic } \\
\text { re-evaluation }\end{array}$ & $\begin{array}{l}\text { Misdiagnosed/ } \\
\text { followed upt }\end{array}$ & $\begin{array}{l}\text { Misdiagnosed } \\
\quad(\%)\end{array}$ \\
\hline Slater $^{23}$ & $1951-5$ & 108 & $87 \%$ & Uncertain & $\begin{array}{l}\text { Neurology, } \\
\text { inpatients }\end{array}$ & $\begin{array}{l}\text { Interview, case note } \\
\text { review, GP }\end{array}$ & $32 / 97$ & $33 \%$ \\
\hline $\operatorname{Reed}^{4}$ & 1949-64 & 136 & $94 \%$ & $\begin{array}{l}\text { Pain }(12.5 \%) \text {, weakness }(10 \%) \text {, non-epileptic } \\
\text { seizure/loss of consciousness }(9 \%) \text {, fugue }(9 \%) \text {, } \\
\text { movement disorder }(7.5 \%) \text {, vomiting }(3 \%) \text {, } \\
\text { amnesia }(2.5 \%) \text {, other conversion/dissociative } \\
(10 \%) \text {, hysteria not otherwise specified }(35 \%)\end{array}$ & $\begin{array}{l}\text { Psychiatry, } \\
\text { inpatients }\end{array}$ & $\begin{array}{l}\text { Case note review, } \\
\text { self report, GP }\end{array}$ & $29 / 113$ & $26 \%$ \\
\hline Lewis $^{5}$ & $1969-74$ & 114 & NA & Uncertain & $\begin{array}{l}\text { Psychiatry, } \\
\text { uncertain }\end{array}$ & $\begin{array}{l}\text { Interview, self } \\
\text { report, GP }\end{array}$ & $4 / 98$ & $4 \%$ \\
\hline Stefansson $^{6}$ & $1960-9$ & 42 & $100 \%$ & $\begin{array}{l}\text { Weakness }(20 \%) \text {, sensory symptom }(14 \%) \text {, } \\
\text { non-epileptic seizure/loss of consciousness }(14 \%) \text {, } \\
\text { vision }(13 \%) \text {, pain }(56 \%) \text {, breathing }(28 \%) \text {, } \\
\text { deafness }(11 \%)\end{array}$ & $\begin{array}{l}\text { Psychiatry, } \\
\text { uncertain }\end{array}$ & Case note review & $8 / 64$ & $13 \%$ \\
\hline Watson $^{7}$ & $1964-6$ & 120 & NA & Uncertain & $\begin{array}{l}\text { Military hospital, } \\
\text { uncertain }\end{array}$ & Case note review & $10 / 40$ & $25 \%$ \\
\hline$\overline{W i g^{8}}$ & $1971-2$ & 90 & $67 \%$ & $\begin{array}{l}\text { Neurological symptom-for example, aphonia, } \\
\text { paresis + episodic possession states }\end{array}$ & $\begin{array}{l}\text { Psychiatry, } \\
\text { outpatients }\end{array}$ & Interview & $3 / 54$ & $6 \%$ \\
\hline Kathol $^{9}$ & $1973-9$ & 48 & $53 \%$ & Vision $(100 \%)$ & $\begin{array}{l}\text { Ophthalmology } \\
\text { outpatients }\end{array}$ & $\begin{array}{l}\text { Interview, neuro } \\
\text { re-exam }\end{array}$ & 1/ 42 & $2 \%$ \\
\hline Baker $^{10}$ & $1944-84$ & 20 & $80 \%$ & Weakness $(100 \%)$ & $\begin{array}{l}\text { Neurology, } \\
\text { inpatients }\end{array}$ & GP & $0 / 16$ & $0 \%$ \\
\hline Meierkord ${ }^{11}$ & 1975-89 & 60 & $64 \%$ & $\begin{array}{l}\text { Non-epileptic seizure/loss of consciousness } \\
(100 \%)\end{array}$ & $\begin{array}{l}\text { Neurology, } \\
\text { inpatients }\end{array}$ & GP, case note review & $0 / 70$ & $0 \%$ \\
\hline Kristensen $^{12}$ & 1977-85 & 70 & $100 \%$ & $\begin{array}{l}\text { Non-epileptic seizure/loss of consciousness } \\
(100 \%)\end{array}$ & $\begin{array}{l}\text { Neurology, } \\
\text { inpatients }\end{array}$ & $\begin{array}{l}\text { Interview, GP, case } \\
\text { note review }\end{array}$ & $2 / 28$ & $7 \%$ \\
\hline Betts $^{13}$ & $1983-8$ & 60 & $86 \%$ & $\begin{array}{l}\text { Non-epileptic seizure/loss of consciousness } \\
(100 \%)\end{array}$ & $\begin{array}{l}\text { Neurology, } \\
\text { inpatients }\end{array}$ & Interview, GP & 7/97 & $7 \%$ \\
\hline Chandrasekaran $^{14}$ & 1987 & 60 & $75 \%$ & $\begin{array}{l}\text { Non-epileptic seizure/loss of consciousness (63\%), } \\
\text { weakness }(21 \%) \text {, dissociative disorders }(16 \%)\end{array}$ & $\begin{array}{l}\text { Psychiatry, } \\
\text { outpatients }\end{array}$ & Interview & $0 / 38$ & $0 \%$ \\
\hline Kent ${ }^{16}$ & $1984-6$ & 50 & $34 \%$ & Uncertain & $\begin{array}{l}\text { Inpatients and } \\
\text { outpatients }\end{array}$ & Interview & $4 / 33$ & $12 \%$ \\
\hline Couprie $^{15}$ & $1982-9$ & 54 & $97 \%$ & $\begin{array}{l}\text { Weakness }+/ \text { - sensory symptom }(73 \%) \text {, gait } \\
(12 \%) \text {, sensory symptom }(5 \%) \text {, dysphonia }(5 \%) \text {, } \\
\text { vision }(2 \%) \text {, movement disorder }(2 \%)\end{array}$ & $\begin{array}{l}\text { Neurology, } \\
\text { inpatients }\end{array}$ & Interview & 2/58 & $3 \%$ \\
\hline Walczak $^{17}$ & $1991-3$ & 15 & $71 \%$ & $\begin{array}{l}\text { Non-epileptic seizure/loss of consciousness } \\
(100 \%)\end{array}$ & $\begin{array}{l}\text { Neurology, } \\
\text { inpatients }\end{array}$ & Interview & $0 / 51$ & $0 \%$ \\
\hline Ramani $^{18}$ & $1985-94$ & 55 & $62 \%$ & $\begin{array}{l}\text { Non-epileptic seizure/loss of consciousness } \\
(100 \%)\end{array}$ & $\begin{array}{l}\text { Neurology, } \\
\text { uncertain }\end{array}$ & Interview & $0 / 21$ & $0 \%$ \\
\hline Mace $^{19}$ & $1978-80$ & 117 & $95 \%$ & $\begin{array}{l}\text { Weakness/movement disorder }(42 \%) \text {, non-epileptic } \\
\text { seizure/loss of consciousness }(37 \%) \\
\text { vision/dysphonia }(8 \%) \text {, sensory symptom }(5 \%), \\
\text { amnesia }(4 \%) \text {, other }(3 \%)\end{array}$ & $\begin{array}{l}\text { Psychiatry, } \\
\text { inpatients and } \\
\text { outpatients }\end{array}$ & Interview & $3 / 75$ & $15 \%$ \\
\hline Binzer $^{20}$ & $1992-5$ & 44 & $100 \%$ & Weakness $(100 \%)$ & $\begin{array}{l}\text { Neurology, } \\
\text { inpatients }\end{array}$ & $\begin{array}{l}\text { Interview, neuro } \\
\text { re-exam }\end{array}$ & $0 / 30$ & $0 \%$ \\
\hline Crimlisk $^{21}$ & 1989-91 & 72 & $88 \%$ & Weakness $(48 \%)$, movement disorder $(52 \%)$ & $\begin{array}{l}\text { Neurology, } \\
\text { inpatients }\end{array}$ & $\begin{array}{l}\text { Interview, neuro } \\
\text { re-exam }\end{array}$ & $3 / 64$ & $5 \%$ \\
\hline Jongsma $^{22}$ & $1991-4$ & 45 & $85 \%$ & $\begin{array}{l}\text { Non-epileptic seizure/loss of consciousness } \\
(100 \%)\end{array}$ & $\begin{array}{l}\text { Neurology, } \\
\text { inpatients }\end{array}$ & Self report & $0 / 28$ & $0 \%$ \\
\hline Selwa ${ }^{23}$ & $1994-6$ & 33.5 & $67 \%$ & $\begin{array}{l}\text { Non-epileptic seizure/loss of consciousness } \\
(100 \%)\end{array}$ & $\begin{array}{l}\text { Neurology, } \\
\text { inpatients }\end{array}$ & Interview & $0 / 57$ & $0 \%$ \\
\hline Moene $^{24}$ & $1991-6$ & 29 & $100 \%$ & $\begin{array}{l}\text { Weakness/movement disorder (95\%), sensory } \\
\text { symptom }(5 \%)\end{array}$ & $\begin{array}{l}\text { Neurology, } \\
\text { inpatients }\end{array}$ & $\begin{array}{l}\text { Interview, neuro } \\
\text { re-exam }\end{array}$ & $9 / 85$ & $11 \%$ \\
\hline Feinstein $^{25}$ & $1993-9$ & 38 & $51 \%$ & Movement disorders $(100 \%)$ & $\begin{array}{l}\text { Neurology, } \\
\text { outpatients }\end{array}$ & Interview & $0 / 45$ & $0 \%$ \\
\hline Schuepbach $^{26}$ & $1986-7$ & 60 & $93 \%$ & Conversion disorder (100\%) & $\begin{array}{l}\text { Psychosomatic } \\
\text { clinic, inpatients } \\
\text { and outpatients }\end{array}$ & GP & $0 / 39$ & $0 \%$ \\
\hline Teasell ${ }^{27}$ & $1991-2001$ & $?$ & $100 \%$ & $\begin{array}{l}\text { Conversion disorder ( } 100 \% \text {, all with disability } \\
\text { requiring rehabilitation) }\end{array}$ & $\begin{array}{l}\text { Rehabilitation, } \\
\text { inpatients }\end{array}$ & $\begin{array}{l}\text { Interview, neuro } \\
\text { re-exam }\end{array}$ & $5 / 45$ & $11 \%$ \\
\hline Stone $e^{28}$ & 1985-92 & 126 & $82 \%$ & Weakness $(55 \%)$, sensory symptom (45\%) & $\begin{array}{l}\text { Neurology, } \\
\text { inpatients }\end{array}$ & GP, self report & $1 / 49$ & $2 \%$ \\
\hline Toth $^{29}$ & $1998-2001$ & 16 & $88 \%$ & $\begin{array}{l}\text { Weakness+sensory symptom }(33 \%) \text {, sensory } \\
\text { symptom }(67 \%)\end{array}$ & $\begin{array}{l}\text { Neurology, } \\
\text { outpatients }\end{array}$ & $\begin{array}{l}\text { Interview, neuro } \\
\text { re-exam }\end{array}$ & $0 / 29$ & $0 \%$ \\
\hline
\end{tabular}

$\mathrm{NA}=$ not available.

${ }^{*}$ Median follow-up=58 months; median follow-up rate=86\%.

†Number misdiagnosed=(misdiagnoses+death attributable to misdiagnosis)/all patients followed up (alive and dead): 123/1466 (5\%).

Duration and completeness of follow-up

The median duration of follow-up was five years with a mean follow-up rate of $86 \%$. Five studies lost more than $30 \%$ to followup $^{8911182325}$ and in two the number was unknown. ${ }^{57}$
Method of diagnostic re-evaluation

The ideal standard for diagnostic re-evaluation is for the patient to be examined by an experienced physician (usually a neurologist) with additional investigations as required. No study clearly 


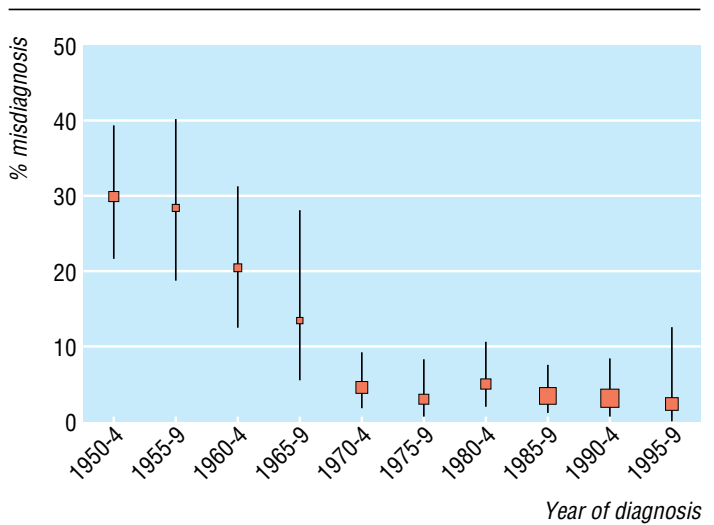

Fig 1 Misdiagnosis of conversion symptoms and hysteria (mean \%, 95\% confidence intervals, random effects) plotted at midpoint of five year intervals according to when patients were diagnosed. Size of each point is proportional to number of subjects at each time point (total $n=1466$ )

met this standard: only six studies reported re-examination by a physician, ${ }^{91} 22242729$ and none reported on investigations. Other studies used only a combination of interview, self report, and information from general practice records (table). Although one might expect disease diagnoses such as severe spastic paraparesis to be detected by simple reassessment, others may be missed because they are obscure (for example, paroxysmal hemidystonia $^{21}$ ), too mild (for example, mild multiple sclerosis), or because the initial diagnosis of conversion disorder has prejudiced an open minded re-evaluation.

\section{Patients with disease and conversion symptoms}

Three studies reported on patients who had an initial diagnosis of both disease and conversion symptoms that was subsequently revised to one of disease alone. ${ }^{319}{ }^{24}$ We did not count these 28 cases as misdiagnoses, and additional information from the author of one study led to two more patients being placed in that category. ${ }^{19}$

\section{Nature of misdiagnosis and cause of death}

The nature of the revised diagnosis was reported in 68 out of 123 cases. Epilepsy $(\mathrm{n}=13)$, movement disorders $(\mathrm{n}=6)$, and multiple sclerosis $(n=6)$ were most common. The presenting symptom of the misdiagnosed patients was described in 52 cases; the most common were gait disorder $(n=17)$, seizures $(n=13)$,

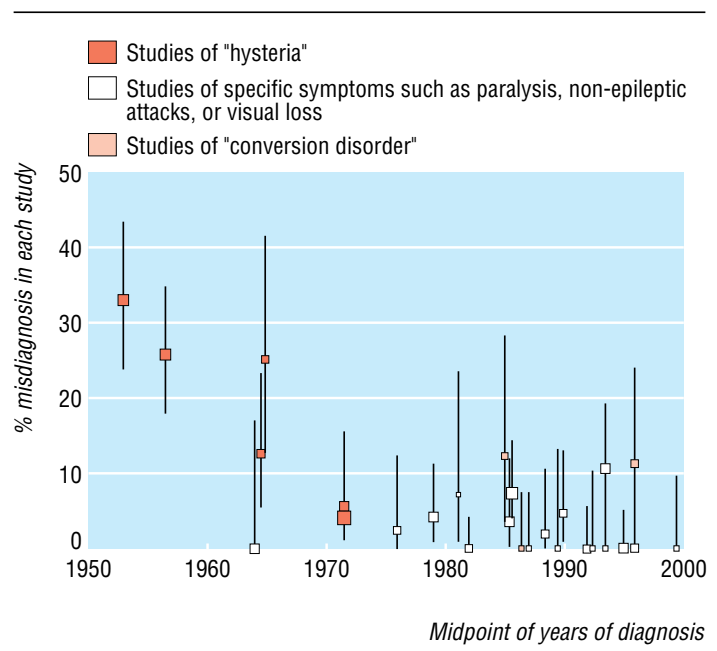

Fig 2 Individual study data plotted at midpoint of recruitment period with 95\% exact binomial confidence intervals and movement disorder $(n=5)$. In the eight cases in which an initial diagnosis of pseudoseizures was later changed to one of epilepsy (and in which the seizure type was described), five had frontal lobe epilepsy-a cause of unusual attacks that can sometimes be missed even by videotelemetry. Possible reasons for misdiagnosis mentioned in the papers were bizarre presenting symptoms and the presence of a psychiatric history. ${ }^{44-45}{ }^{46}$ Nearly a third of the recorded deaths at follow-up (13/47) were by suicide. Other causes of death included immobility (without a new organic diagnosis) $(n=2)$, vascular disease $(n=7)$, and cancer $(\mathrm{n}=8$, one brain tumour).

\section{Discussion}

In the study of misdiagnosis of conversion symptoms or hysteria the overall pooled proportion for the whole period was $8.4 \%$ $(7.1 \%$ to $9.9 \%)$. This overall figure, however, disguises a change over time from $29 \%$ in the 1950 s and $17 \%$ in the 1960 s to a consistently low rate of $4 \%$ for every decade since then.

There are two possible explanations for this decline. Firstly, it could be that diagnostic methods could have improved. Against this hypothesis, however, is the observation that the five yearly misdiagnosis rate fell to $4.4 \%(2.1 \%$ to $9.2 \%)$ in the period $1970-4$, which is before computerised tomography became generally available. ${ }^{48}$ So although modern investigations such as neuroimaging and video electroencephalography are likely to have increased the diagnostic accuracy in more recent studies, our data suggest that they have not been as important as previously believed. This interpretation is supported by the fact that many of the misdiagnosed patients were rediagnosed with conditions such as epilepsy and movement disorders, which even now rely predominantly on a clinical diagnosis. Secondly, early studies may have reported artefactually high rates of misdiagnosis because of poor study methods. In favour of this hypothesis is the observation that the six studies that contributed results to data from the $1950 \mathrm{~s}$ and $1960 \mathrm{~s}^{3-7}{ }^{10}$ were all poor quality. Figure 2 shows that studies with poor case definition tended to have a higher rate of misdiagnosis.

Although a $4 \%$ misdiagnosis rate could still be seen as too high, it must be considered alongside rates for other neurological and psychiatric conditions. For example, up to a quarter of patients with a diagnosis of epilepsy have other conditions, most commonly syncope. ${ }^{49}$ In another study, $8 \%$ of patients with a diagnosis of multiple sclerosis were later found to have conversion disorder, illustrating that misdiagnosis can also happen in the opposite direction..$^{50}$

Patients can have both disease and conversion symptoms. Failure to distinguish studies of comorbidity from true misdiagnosis of organic disease is an error noted in some of the papers reviewed. ${ }^{3}$

\section{Limitations}

We have outlined the limitations of the component studies reported in this review, including poor definition of the symptoms studied, retrospective study design, cohorts recruited from tertiary, predominantly inpatient settings, and inadequate methods of diagnostic re-evaluation.

We included only studies published since 1965 . Some studies were published before this date. ${ }^{51-55}$ They were of variable quality with misdiagnosis rates of between $13 \%$ and $17 \%$, figures that do not necessitate any change in our conclusions. We did not include studies of other somatoform disorders or of dysphonia and globus pharyngis (which are both conversion symptoms). We are not aware of any studies of patients with these diagnoses that would alter our general conclusions. ${ }^{56}$ We may have 


\section{What is already known on this topic}

Older studies reported unacceptable rates of misdiagnosis of conversion symptoms and hysteria

More recent studies have found lower rates, similar to those seen in other neurological and psychiatric disorders

\section{What this study adds}

The reported rate of misdiagnosis of conversion symptoms has, on average, been $4 \%$ since 1970

This decline occurred before the widespread introduction of computed tomography, suggesting that this was not the reason for improved diagnostic accuracy

Early studies were of poor quality and often used a vague definition of "hysteria"

The most commonly missed symptoms related to disease were gait and movement disorders

underestimated the latency between diagnosis and publication for four studies where information was unavailable, ${ }^{517} 1827$ although this would tend to emphasise rather than contradict our conclusions. Finally, we acknowledge the conceptual limitations of defining a symptom as being "unexplained by disease." While we have used this to mean no conventionally defined pathology, we recognise that all symptoms must ultimately have neurobiological correlates as illustrated by recent functional imaging studies of patients with conversion symptoms. ${ }^{57}$

\section{Implications}

In modern studies the proportion of patients diagnosed as having conversion symptoms that subsequently turn out to be due to disease is low. The decline from earlier reports of a high rate probably reflect the poor methods used in earlier studies more than an improvement in modern diagnosis resulting from the availability of brain imaging. Misdiagnosis may be more common in patients with gait and movement disorders and in those with a psychiatric history.

While concern about misdiagnosis may be helpful in encouraging a thorough assessment, it may be unhelpful by leading to overinvestigation and delayed treatment for what are potentially reversible conversion symptoms. We suggest that the balance between concern about missing disease and neglecting the value of a positive diagnosis of a reversible conversion symptom needs to be redressed.

We thank A Feinstein, F C Moene, C J Mace, M E Sabbioni, L M Selwa, M R Trimble, and R Will for their help with queries about their data.

Contributors: JS initiated the study. JS and RS designed the study. JS, RS, AC, CW, and MS carried out data extraction. SL and RP provided statistical advice. All authors participated in writing the manuscript. MS is the guarantor.

Funding: JS was supported by the chief scientist office, Scotland.

Competing interests: None declared.

Ethical approval: Not required.

1 Akagi H, House A. The epidemiology of hysterical conversion. In: Halligan PW, Bass C, Marshall JC, eds. Contemporary approaches to the study of hysteria. Oxford: Oxford University Press, 2001:73-87.

2 Slater ET. Diagnosis of "hysteria." BMJ 1965;i:1395-9.

3 Slater ET, Glithero E. A follow-up of patients diagnosed as suffering from "hysteria." $J$ Psychosom Res 1965;9:9-13

4 Reed JL. The diagnosis of "hysteria". Psychol Med 1975;5:13-7.
5 Lewis A. The survival of hysteria. Psychol Med 1975:5:9-12.

6 Stefansson JG, Messina JA, Meyerowitz S. Hysterical neurosis, conversion type: clinical and epidemiological considerations. Acta Psychiatr Scand 1976;53:119-38.

Watson CG, Buranen C. The frequency and identification of false positive conversion reactions. J Nerv Ment Dis 1979;167:243-7.

8 Wig NN, Mangalwedhe K, Bedi H, Murthy RS. A follow-up study of hysteria. Indian J Psychiatry 1982;24:120-5.

9 Kathol RG, Cox TA, Corbett JJ, Thompson HS. Functional visual loss. Follow-up of 42 cases. Arch Ophthalmol 1983;101:729-35.

10 Baker JH, Silver JR. Hysterical paraplegia. J Neurol Neurosurg Psychiatry 1987;50:375-82.

11 Meierkord H, Will B, Fish D, Shorvon S. The clinical features and prognosis of pseudoseizures diagnosed using video-EEG telemetry. Neurology 1991;41:1643-6.

12 Kristensen O, Alving J. Pseudoseizures-risk factors and prognosis. A case-control study. Acta Neurol Scand 1992;85:177-80.

13 Betts T, Boden S. Diagnosis, management and prognosis of a group of 128 patients with non-epileptic attack disorder. Part I. Seizure 1992;1:19-26.

14 Chandrasekaran R, Goswami U, Sivakumar V, Chitralekha. Hysterical neurosis-a follow-up study. Acta Psychiatr Scand 1994;89:78-80.

15 Couprie W, Wijdicks E-FM, Rooijmans H-GM, van Gijn J. Outcome in conversion disorder: a follow-up study. J Neurol Neurosurg Psychiatry 1995;58:750-2.

16 Kent DA, Tomasson K, Coryell W. Course and outcome of conversion and somatization disorders. A four-year follow-up. Psychosomatics 1995;36:138-44.

17 Walczak TS, Papacostas S, Williams DT, Scheuer ML, Lebowitz N, Notarfrancesco A. Outcome after diagnosis of psychogenic nonepileptic seizures. Epilepsia $1995 ; 36: 1131-7$

18 Ramani V, Girgenti L, Hickling E. Outcome after diagnosis of psychogenic nonepileptic seizures (PNES). Epilepsia 1996;37:416-7.

19 Mace CJ, Trimble MR. Ten-year prognosis of conversion disorder. Br J Psychiatry 1996;169:282-8.

20 Binzer M, Kullgren G. Motor conversion disorder. A prospective 2- to 5-year follow-up study. Psychosomatics 1998;39:519-27.

21 Crimlisk HL, Bhatia K, Cope H, David A, Marsden CD, Ron MA. Slater revisited: 6 year follow up study of patients with medically unexplained motor symptoms. BMJ 1998;316:582-6.

22 Jongsma MJ, Mommers JM, Renier WO, Meinardi H. Follow-up of psychogenic, non-epileptic seizures: a pilot study-experience in a Dutch special centre for epilepsy. Seizure 1999;8:146-8.

23 Selwa LM, Geyer J, Nikakhtar N, Brown MB, Schuh LA, Drury I. Nonepileptic seizure outcome varies by type of spell and duration of illness. Epilepsia 2000;41:1330-4.

24 Moene FC, Landberg EH, Hoogduin KA, Spinhoven P, Hertzberger LI, Kleyweg RP, et al. Organic syndromes diagnosed as conversion disorder: identification and frequency in a study of 85 patients. J Psychosom Res 2000;49:7-12.

25 Feinstein A, Stergiopoulos V, Fine J, Lang AE. Psychiatric outcome in patients with a psychogenic movement disorder: a prospective study. Neuropsychiatry Neuropsychol psychogenic movement disor
Behav Neurol 2001;14:169-76.

26 Schuepbach WM, Adler RH, Sabbioni ME. Accuracy of the clinical diagnosis of "psychogenic disorders" in the presence of physical symptoms suggesting a general medical condition: a 5-year follow-up in 162 patients. Psychother Psychosom 2002;71:11-7.

27 Teasell RW, Shapiro AP. Misdiagnosis of conversion disorders. Am J Phys Med Rehabil 2002;81:236-40.

28 Stone J, Sharpe M, Rothwell PM, Warlow CP. The 12 year prognosis of unilateral functional weakness and sensory disturbance. J Neurol Neurosurg Psychiatry 2003;74:591-6.

29 Toth C. Hemisensory syndrome is associated with a low diagnostic yield and a nearly uniform benign prognosis. J Neurology Neurosurg Psychiatry 2003;74:1113-6.

30 Groeneweg CE, Sidler D, Vasella DL, Adler RH. [Missed somatic disease: justified fear or chimera?]. Schweiz Rundsch Med Prax 1991;80:529-36.

31 Fishbain DA, Goldberg M. The misdiagnosis of conversion disorder in a psychiatric emergency service. Gen Hosp Psychiatry 1991;13:177-81.

32 Parra J, Iriarte J, Kanner AM. Are we overusing the diagnosis of psychogenic non-epileptic events? Seizure 1999;8:223-7.

33 Krill AE, Newell FW. The diagnosis of ocular conversion reaction involving visual function. Arch Ophthalmol 1968;79:254-61.

34 Raskin M, Talbott JA, Meyerson AT. Diagnosis of conversion reactions. Predictive value of psychiatric criteria. JAMA 1966;197:530-4.

35 Brooks DN, Geoghegan PM. Non-organic hearing loss in young persons: transient epiBrooks DN, Geoghegan PM. Non-organic hearing loss in young person:
sode or indicator of deep-seated difficulty. Br J Audiol 1992;26:347-50.

36 Barris MC, Kaufman DI, Barberio D. Visual impairment in hysteria. Doc Ophthalmol 1992;82:369-82

37 Whitlock FA. The aetiology of hysteria. Acta Psychiatr Scand 1967;43:144-62.

38 McKegney FP. The incidence and characteristics of patients with conversion reactions I. A general hospital consultation service sample. Am J Psychiatry 1967;124:542-5.

39 Merskey H, Buhrich NA. Hysteria and organic brain disease. Br J Med Psychol 1975;48:359-66.

40 Eldridge R, Riklan M, Cooper IS. The limited role of psychotherapy in torsion dystonia. Experience with 44 cases. JAMA 1969;210:705-8.

41 Lesser RP, Fahn S. Dystonia: a disorder often misdiagnosed as a conversion reaction. Am J Psychiatry 1978;135:349-52.

42 Cooper IS, Cullinan T, Riklan M. The natural history of dystonia. Adv Neurol 1976;14:157-69

43 Marsden CD, Harrison MJ. Idiopathic torsion dystonia (dystonia musculorum deformans). A review of forty-two patients. Brain 1974;97:793-810.

44 Miller BL, Benson DF, Goldberg MA, Gould R. Misdiagnosis of hysteria. Am Fam Physician 1986;34:157-60.

45 Glick TH, Workman TP, Gaufberg SV. Suspected conversion disorder: foreseeable risks and avoidable errors. Acad Emerg Med 2000;7:1272-7.

46 Kutz I, Garb R, Kuritzky A. Diagnosis of misdiagnosis: on some of the origins and functions of psychophysical misdiagnosis. Gen Hosp Psychiatry 1983;5:197-202.

47 Wessely S. Discrepancies between diagnostic criteria and clinical practice. In: Halligan P, Bass C, Marshall JC, eds. Contemporary approaches to the science of hysteria. Oxford: Oxford University Press, 2001:63-79.

48 Cabanis EA, Iba-Zizen MT. A history of neuroradiology (1895-2002). Paris: XVIIth Symposium Neuroradiologicum, 2002 
49 Smith D, Defalla BA, Chadwick DW. The misdiagnosis of epilepsy and the management of refractory epilepsy in a specialist clinic. QJ Med 1999;92:15-23.

50 Hankey GJ, Stewart-Wynne EG. Pseudo-multiple sclerosis: a clinico-epidemiological study. Clin Exp Neurol 1987;24:11-9.

51 Gatfield PD, Guze SB. Prognosis and differential diagnosis of conversion reactions. Dis Nerv Sys 1962;23:623-31.

52 Carter AB. The prognosis of certain hysterical symptoms. BMJ 1949;i:1076-9.

53 Tissenbaum MJ, Harter HM. Organic neurological syndromes diagnosed as functional disorders. JAMA 1951;147:1519-21.

54 Ziegler DK, Paul N. On the natural history of hysteria in women (a follow up study 20 years after hospitalisation). Dis Nerv Syst 1954;15:301-6.

55 Ljungberg L. Hysteria: a clinical, prognostic and genetic study. Acta Psychiat Neurol Scand 1957; suppl 112:1-162.

56 Rief W, Hiller W, Geissner E, Fichter MM. A two-year follow-up study of patients with somatoform disorders. Psychosomatics 1995;36:376-86.

57 Vuilleumier P, Chicherio C, Assal F, Schwartz S, Skusman D, Landis T. Functional neuroanatomical correlates of hysterical sensorimotor loss. Brain 2001;124:1077-90.
(Accepted 16 August 2005)

doi 10.1136/bmj.38628.466898.55

School of Molecular and Clinical Medicine, University of Edinburgh, Edinburgh EH4 2XU

Jon Stone consultant neurologist

Roger Smyth consultant psychiatrist

Alan Carson consultant neuropsychiatrist

Steff Lewis medical statistician

Robin Prescott director, medical statistics unit

Charles Warlow professor of medical neurology

Michael Sharpe professor of psychological medicine and symptoms research

Correspondence to:J Stone Jon.Stone@ed.ac.uk 